\title{
PERBANDINGAN NILAI LAJU ENDAP DARAH ANTARA PENGUKURAN METODE MANUAL WESTERGREN DAN ALAT AUTOMATIK PADA SAMPEL DARAH SITRAT PENDERITA TB PARU DI RSUD. dr. DRADJAT PRAWIRANEGARA SERANG
}

\author{
Destri Siti Juleha ${ }^{1^{*}}$, Deviani Utami ${ }^{2}$, Ade Utia Detty ${ }^{3}$, \\ ${ }^{1 *}$ Program Studi Kedokteran Fakultas Kedokteran Universitas Malahayati \\ ${ }^{2,3}$ Dosen Fakultas Kedokteran Universitas Malahayati \\ Email korespondensi: disinidestri@gmail.com
}

\begin{abstract}
Background: Erythrocytes Sedimentation Rate (ESR) is a test to determine the rate of erythrocytes settling blood containing anticoagulants in a vertical tube within a certain time. ESR are generally used to check and monitor for tissue damage, inflammation and indicate disease. ESR examination can be done by manual and automatic methods. LED levels in pulmonary TB patients generally have increased.

Objectives: Knowing the difference in the measurement results of the erythrocytes sedimentation rate (ESR) between the Westergen manual and automatic methods in patients with pulmonary tuberculosis.

Methods: Laboratory experiments with a post test only approach. The number of samples was 30 people and was taken by purposive sampling. The research data were obtained from the results of the ESR examination using the Westergren manual and automatic methods.

Results: examination of the sedimentation rate of healthy respondents used Westergren method had an average of $9,40 \mathrm{~mm} /$ hour while in the automatic method $10,15 \mathrm{~mm} /$ hour. The examination of sedimentation rate of pulmonary tuborculocis respondents with the Westergren method had an average of $66,13 \mathrm{~mm} /$ hour, while the Automatic method was $67,80 \mathrm{~mm} /$ hour. There was no significant difference in the mean value of ESR between the measurement method used manual Westergren and Automatic methods in patients with pulmonary tuborculosis ( $p=0,878$ ).

Conclusion: There is no significant difference in the mean value of ESR between measurements using the manual Westergren method and automatic in patients with pulmonary tuberculosis.
\end{abstract}

Keywords : Erythrocytes Sedimentation Rate, Method, Westergren, Automatic

PERBANDINGAN NILAI LAJU ENDAP DARAH ANTARA PENGUKURAN METODE MANUAL WESTERGREN DAN ALAT AUTOMATIK PADA SAMPEL DARAH SITRAT PENDERITA TB PARU DI RSUD. Dr. DRADJAT PRAWIRANEGARA SERANG

Latar Belakang: Laju Endap Darah (LED) adalah pemeriksaan untuk menentukan kecepatan eritrosit mengendap dalam darah yang berisi antikoagulan pada suatu tabung vertikal dalam waktu tertentu. LED pada umumnya digunakan untuk mendeteksi dan memantau adanya kerusakan jaringan, inflamasi dan menunjukan adanya penyakit. Pemeriksaan LED dapat dilakukan dengan metode 
manual dan automatik. Kadar LED pada penderita TB Paru umumnya mengalami peningkatan.

Tujuan: Mengetahui perbedaan hasil pengukuran Laju Endap Darah (LED) antara metode manual Westergen dan Automatik pada Penderita TB Paru.

Metodologi: Eksperimen laboratorik dengan pendekatan post test only. Jumlah sampel 30 orang dan diambil dengan purposive sampling. Data penelitian diperoleh dari hasil pemeriksaan LED menggunakan metode manual Westergren dan Automatik.

Hasil: Pemeriksaan Laju Endap Darah pada responden sehat metode Westergren memiliki rata-rata $9,40 \mathrm{~mm} / \mathrm{jam}$ sedangkan pada metode Automatik 10,15 $\mathrm{mm} / \mathrm{jam}$. Pemeriksaan Laju Endap Darah pada responden TB Paru metode Westergren memiliki rata-rata $66,13 \mathrm{~mm} /$ jam sedangkan pada metode Automatik $67,80 \mathrm{~mm} / \mathrm{jam}$. Tidak terdapat perbedaan rata-rata nilai LED yang signifikan antara pengukuran menggunakan metode manual Westergren dan Automatik pada penderita TB Paru $(p=0,878)$.

Kesimpulan: Tidak terdapat perbedaan rata-rata nilai LED yang signifikan antara pengukuran menggunakan metode manual Westergren dan Automatik pada penderita TB Paru.

Kata Kunci: Laju Endap Darah, Metode, Westergren, Automatik

\section{PENDAHULUAN}

Pemeriksaan hematologi merupakan salah satu pemeriksaan yang dapat digunakan sebagai penunjang diagnosis yang berkaitan dengan terapi dan prognosis. Untuk mendapatkan diagnosis yang tepat diperlukan hasil yang teliti dan cepat. Dalam perkembangannya, berbagai tes laboratorik untuk diagnosis mengalami perbaikan dan kemajuan dalam menunjang pelayanan kesehatan yang efisien, teliti dan cepat. Salah satunya adalah tes laju endap darah (Ibrahim et al., 2006).

Laju Endap Darah (LED) adalah pemeriksaan untuk menentukan kecepatan eritrosit mengendap dalam darah yang berisi antikoagulan pada suatu tabung vertikal dalam waktu tertentu. LED pada umumnya digunakan untuk mendeteksi dan memantau adanya kerusakan jaringan, inflamasi dan menunjukan adanya penyakit (Nugraha, 2015).

Pemeriksaan LED adalah
pemeriksaan darah $\begin{array}{r}\text { yang } \\ \text { menggambarkan }\end{array}$
$\begin{aligned} & \text { kecepatan } \\ & \text { pengendapan eritrosit dalam plasma } \\ & \text { darah yang }\end{aligned}$ menggunakan

antikoagulan Natrium Sitrat 3,8\% dan dinyatakan dalam $\mathrm{mm} / \mathrm{jam}$. Ada beberapa metode pemeriksaan LED diantaranya metode Westergren dan Wintrobe, kedua metode ini merupakan cara manual. Metode Westergren merupakan metode yang disarankan oleh International Communitte for Standarization in Hematology (ICSH) (Liswanti, 2014).

Seiring dengan meningkatnya jumlah pemeriksaan, maka waktu yang diperlukan akan semakin banyak, padahal waktu yang diperlukan untuk tes LED maksimal 2 jam. Pemeriksaan LED cara lain yang banyak dilakukan antara lain cara manual miring dan automatik. Sampai saat ini di laboratorium rumah sakit daerah dan puskesmas jika jumlah tes LED banyak, maka tes dilakukan dengan cara memiringkan rak pipet Westergren di kedudukan $45^{\circ}$ selama 7 menit. Hasilnya setara dengan metode Westergren cara tegak selama 1 jam. Tes LED cara miring ini merupakan modifikasi Westergren dan menjadi salah satu pilihan yang dipakai untuk efisiensi waktu walaupun acuannya belum ada. Tes 
LED cara automatik merupakan teknik temuan terbaru yang bertujuan untuk menghindari atau menurunkan resiko terpajannya petugas laboratorium terhadap cemaran bahan yang infeksius (Ibrahim et al., 2006).

Berdasarkan studi literatur awal yang dilakukan oleh peneliti, masih terdapat perbedaan hasil penelitian terkait dengan penggunaan metode manual dan automatik. Hasil penelitian yang dilakukan oleh Wijayanti (2018) di Jombang menunjukkan bahwa tidak terdapat perbedaan hasil pengukuran yang signifikan antara metode manual dan automatik $\quad(p=0,080)$. Sedangkan penelitian yang dilakukan oleh Seran (2018) di Kupang menunjukkan bahwa terdapat perbedaan hasil pengukuran yang signifikan antara metode manual dan automatik $(p=0,000)$.

\section{METODE PENELITIAN}

Jenis penelitian ini adalah eksperimen laboratorik dengan pendekatan post test only. Metode ini membandingkan dua kelompok data dengan menggunakan satu jenis sampel yang sama (darah sitrat). Kelompok satu yaitu pemeriksaan dengan metode manual Westergen, dan kelompok dua yaitu pemeriksaan dengan metode automatik.

Penelitian ini dilakukan di Laboratorium Patologi Klinik RSUD. dr. Dradjat Prawiranegara Serang.

Teknik pengambilan sampel menggunakan random sampling, yaitu pengambilan sampel yang dilakukan secara acak tanpa memperhatikan strata yang ada dalam populasi (Notoatmodjo, 2012). Sampel dalam penelitian ini adalah pasien yang dirujuk melakukan pemeriksaan darah di laboratorium patologi klinik RSUD. dr. Dradjat Prawiranegara Serang sebanyak 30 pasien, yang terdiri dari 15 penderita TB Paru dan 15 orang sehat.

\section{HASIL DAN PEMBAHASAN}

Hasil Penelitian

Hasil penelitian menunjukkan bahwa terdapat perbedaan rata-rata nilai LED yang signifikan antara responden sehat dengan responden penderita TB Paru, baik diukur menggunakan metode manual Westergren $\quad(p=0,000) \quad$ ataupun metode Automatik $(p=0,000)$.

Hasil penelitian ini sejalan dengan penelitian yang dilakukan oleh Ningrum (2017) di Tangerang yang menunjukkan bahwa pada $94,3 \%$ penderita TB Paru terjadi peningkatan nilai LED yang signifikan. Hasil penelitian ini juga sejalan dengan penelitian yang dilakukan oleh Hasnawati (2018) di Makassar yang menunjukkan bahwa terjadi peningkatan nilai LED yang signifikan pada seluruh pasien penderita TB Paru yang diteliti.

Peningkatan nilai LED pada pasien TB Paru terjadi karena infeksinya merupakan infeksi bakteri kronik. Infeksi tuberkulosis merupakan infeksi bakteri intraseluler yang pertama kali dihadapi oleh neutrophil, kemudian bakteri ditangkap oleh makrofag dan Natural Killer cell sehingga menghasilkan sel $T$ CD4+ dan CD8+. Sel T ini kemudian menghasilkan IFN- $\gamma$ dan TNF. IFN- $\gamma$ dan TNF memiliki peranan dalam mengaktivasi makrofag. Adanya aktifitas peradangan aktif menyebabkan neutrofil memfagositosis bakteri dengan menggunakan anyaman yang mengandung sejumlah faktor antibakteri seperti elastase, catephsin, mieloperoksidase (MPO) dan laktoferin. Anyaman tersebut merupakan protein, selain itu aktifitas fagositosis juga mengaktifkan protein dari sistem komplemen yang merupakan protein fase akut, peningkatan protein fase akut tersebut meningkatkan agregasi eritrosit membentuk rouleaux 
sehingga meningkatkan nilai laju endap darah (Rinaldi and Sudoyo, 2009; Abul, Andrew and Shiv, 2012; Subowo, 2013; Ningrum, 2017).

Hasil penelitian menunjukkan bahwa tidak terdapat perbedaan ratarata nilai LED yang signifikan antara pengukuran menggunakan metode manual Westergren dan Automatik pada penderita TB Paru $(p=0,878)$.

Hasil penelitian ini sejalan dengan penelitian yang dilakukan oleh Sukarmin dan Iqlima (2019) di Bekasi yang menunjukkan bahwa tidak terdapat perbedaan nilai LED yang signifikan antara pengukuran menggunakan metode manual dan automatik $(p=0,340)$. Hasil penelitian ini juga sejalan dengan penelitian yang dilakukan oleh Satri (2016) di Jakarta yang menunjukkan bahwa dengan tingkat keperecayaan 95\%, tidak terdapat perbedaan nilai LED yang signifikan antara metode konvensional dan otomatik $(p=0,406)$. Pemeriksaan Laju Endap Darah (LED) metode automatik dapat digunakan sebagai cara pemeriksaan LED alternatif, sehingga pemeriksaan laboratorium menjadi dua kali lebih cepat, prosedur kerja lebih praktis, tingkat human error lebih sedikit, dan kemungkinan resiko terpajan pada petugas terhadap cemaran bahan infeksius lebih kecil (Nofiyanti, 2017). Namun sebaiknya bagi laboratorium-laboratorium klinik untuk pemeriksaan LED tetap menggunakan metode westergren manual, sebagai evaluasi mengingat bahwa metode tersebut adalah metode yang direkomendasikan oleh International Committee for Standardization in Hematology (ICHS) (Liswanti, 2014). Metode westergren manual memiliki beberapa kelebihan antara lain biaya lebih murah, memiliki skala tabung yang panjang sehingga memungkinkan untuk menghitung skala pembacaan yang besar. Metode westergreen manual juga memiliki kelemahan yaitu cara kerja (adanya gelembung udara, gumpalan darah), bila pemasangan tabung tidak tegak lurus akan mempengaruhi hasil, memerlukan waktu yang lama yaitu 1 jam (Ibrahim et al., 2006).

\section{KESIMPULAN DAN SARAN}

Berdasarkan penelitian dan pembahasan pada bab sebelumnya maka peneliti mengambil kesimpulan sebagai berikut :

1. Terdapat perbedaan rata-rata nilai LED yang signifikan antara responden sehat dengan responden penderita TB Paru, baik diukur menggunakan metode manual Westergren $(p=0,000)$ ataupun metode Automatik $(p=0,000)$. 2. Tidak terdapat perbedaan rata-rata nilai LED yang signifikan antara pengukuran menggunakan metode manual Westergren dan Automatik pada penderita TB Paru $(p=0,878)$.

\section{DAFTAR PUSTAKA}

Abul, A., Andrew, L. and Shiv, P. (2012) Celluler and Molecular Immunology. Philadelphia: Elsevier.

Amin, Z. and Bahar, A. (2014) "Tuberkulosis Paru," in Sudoyo, A. W. et al. (eds.) Buku Ajar Ilmu Penyakit Dalam. VI. Jakarta: Interna Publishing, pp. 2230-2239.

Bakta, I. M. (2016) Hematologi Klinik Ringkas. Jakarta: EGC.

DHiru (2013) Live Blood Analysis. Jakarta: Gramedia Pustaka Utama.

Direktorat Jenderal Pengendalian Penyakit Dan Penyehatan Lingkungan Kementerian Kesehatan RI (2014) Pedoman Nasional Pengendalian Tuberkulosis. Edited by T. N. Dinihari and V. Siagian. Jakarta. Djojodibroto, D. (2013) "Tuberkulosis Paru," in Perdan, T. I. M. and 
Susanto, D. (eds.) Respirologi. 1st ed. Jakarta: EGC, pp. 151168.

Gandasoebrata, R. (2013) Penuntun Laboratorium Klinik. Jakarta: Dian Rakyat.

Guyton, A. C. and Hall, J. E. (2012) Buku Ajar Fisiologi Kedokteran. 11th ed. Edited by L. Y. Rachman et al. Jakarta.

Hartwig, M. S. (2012) "Penyakit Serebrovaskular," in Hartanto, H., Wulansari, P., and Mahanani, D. A. (eds.) Patofisiologi: Konsep Klinis Proses-Proses Penyakit. 6th ed. Jakarta, pp. 1105-1132.

Hasnawati (2018) "Pengaruh Infeksi Mycobacterium Tuberculosis Terhadap Nilai Laju Endap Darah Penderita Tuberculosis Paru di Balai Besar Kesehatan Paru Masyarakat Makassar," Jurnal Media Analis Kesehatan, 1(1), pp. 8-13. doi: 10.32382/mak.v1i1.119.

Ibrahim, N. et al. (2006) "Hasil Tes Laju Endap Darah Cara Manual Dan Automatik," Indonesian Journal of Clinical Pathology and Medical Laboratory, 12(2), p. $45 . \quad$ doi: 10.24293/ijcpml.v12i2.840.

Kementerian Kesehatan RI (2011) Pedoman Interpretasi Data Klinik. Jakarta.

Kiswari, R. (2014) Hematologi dan Transfusi. Jakarta: Erlangga.

Kurniawan, F. B. (2016) Hematologi Praktikum Analis Kesehatan. Jakarta: EGC.

Liswanti, Y. (2014) “Gambaran Laju Endap Darah (Metode Sedimat) Menggunakan Natrium Sitrat 3,8\% dan EDTA Yang Ditambah $\mathrm{NaCl}$ 0,85\%," Jurnal Kesehatan Bakti Tunas Husada, 12(1), p. 226. doi: $10.36465 / j k b$ th. v12i1.83.

Ningrum, W. L. (2017) “Profil Laju Endap Darah Pada Pasien Tuberkulosis Paru Kasus Baru di
RSU Kota Tangerang Selatan," pp. 1-48.

Nofiyanti, I. (2017) Perbedaan Hasil Pemeriksaan Laju Endap Darah Metode Manual dan Automatik. Universitas Muhammadiyah Semarang.

Notoatmodjo, S. (2012) Metodologi Penelitian Kesehatan. Jakarta: Rineka Cipta.

Nugraha, G. (2015) Panduan Pemeriksaan Laboratorium Hematologi Dasar. Jakarta: Trans Info Media.

Rinaldi, I. and Sudoyo, A. W. (2009) "Tuberculosis Paru," in Sudoyo, A. W. et al. (eds.) Buku Ajar Ilmu Penyakit Dalam. V. Jakarta: Interna Publishing, pp. 1163-1164.

Riswanto (2013) Pemeriksaan Laboratorium Hematologi. Yogyakarta: Alfamedika.

Satri, E. (2016) Perbandingan Metode Konvensional dan Otomatik untuk Mengukur Nilai Laju Endap Darah di Rumah Sakit Sumber Waras Jakarta. Universitas Trisakti.

Seran, Y. B. (2018) Perbedaan Hasil Pemeriksaan Laju Endapan Darah Metode Manual dan Automatik (Alifax Roller 20 LC) di Laboratorium RSUD. Prof. Dr. W $Z$ Johhanes Kupang. Universitas Muhammadiyah Semarang.

Subowo (2013) Imunologi Klinik. 2nd ed. Jakarta: Sagung Seto.

Sukarmin, M. and Iqlima, D. (2019) "Perbandingan Hasil Pengukuran Laju Endap Darah Dengan Metode Manual dan Automatic," Jurnal Manajemen Kesehatan Yayasan RS.Dr. Soetomo, 5(1), p. 1. doi: 10.29241/jmk.v5i1.109.

Wallach, J. (2006) Interpretation of Diagnostic Test. 8th ed. New York: Lippincott Williams \& Wilkins.

WHO (2013) “Global Tuberculosis 
Report 2013," World Health

Organization, p. 306. doi: 10.3917/spub.092.0139.

Wijayanti, W. A. (2018) Perbedaan Pengukuran Laju Endap Darah Menggunakan Metode Westergreen Manual dan Automatic. Sekolah Tinggi IImu Kesehatan Insan Cendekia Medika Jombang. 